\title{
Nutritional Status of Dalit Children: A Comparative Study with Non-Dalit Children in Eastern Terai of Nepal
}

\author{
Kafle $T K^{1^{*}}$ Singh $G P^{2}$ Singh $S P^{2}$, Kafle $T K^{3}$
}

\section{Affiliation}

1. Department of Community Medicine, Birat Medical College \& Teaching Hospital, Tankisinwari, Morang, Nepal

2. Department of Community Medicine, Institute of Medical Sciences, BHU, India

3. Nobel Medical College \& Teaching Hospital, Biratnagar, Nepal

\section{ARTICLE INFO}

Article History

Received : 21 March, 2017

Accepted : 21 April, 2017

Published : 30 April, 2017

(c) Authors retain copyright and grant the journal right of first publication with the work simultaneously licensed under Creative Commons Attribution License CC - BY 4.0 that allows others to share the work with an acknowledgment of the work's authorship and initial publication in this journal.

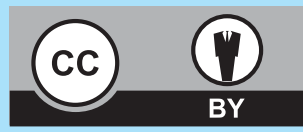

ORA 18

\section{Citation}

Kafle TK, Singh GP, Singh SP, Kafle TK. Nutritional Status of Dalit Children: A Comparative Study with Non-Dalit Children in Eastern Terai of Nepal. BJHS 2017; 2(1)2 : 117-126.

\section{ABSTRACT}

\section{Introduction}

The poor nutritional status of under five children has been considered a serious problem in Nepal for many years. Children need adequate nutrition for their proper physical, emotional as well as psychological development.

\section{Objective}

The objective of this study was to assess and compare the nutritional status of under five children and explore its sociodemographic determinants.

\section{Methodology}

An analytical cross-sectional study was conducted in Eastern Terai, acological belt of Nepal. Predesigned, pretested interview schedule was used to collect the information. Information was collected from 720 Dalit as well as Non-dalit mothers about their youngest children. The nutritional status was measured by using anthropometric measurements.

\section{Results}

In bi-variate analysis the significant difference were observed among children's nutritional status between castes as well as a number of socio-demographic variables however in multivariate analysis only caste, number of Children Ever Born (CEB) and mother's education were found significant determinants of height for age, mother's education was found significant determinant for weight for height and caste, age of children and mother's education were found significant determinants of weight for age of children.

\section{Conclusion}

Dalit children were found much more malnourished than Nondalit. The castes, age of child, CEB to mother and mothers' education were found as the determinants of nutritional status among under-five children.

\section{KEY WORDS}

Children, dalit, height for age, nutritional status 


\section{INTRODUCTION}

Adequate nutrition is prerequisite for all the individuals to maintain their physical as well as mental health; however, more focus has to be given particularly for women and children who are especially vulnerable to it. Childhood is a stage of active growth in all round aspects of a child. Children need varieties of nutrients in this stage, if the nutrient requirements of children are not met, the consequences can be serious for their physical, psychological as well as social development.

The poor nutritional status of under five children has been considered a serious public health issue in Nepal for many years. The most common forms of malnutrition in the country are protein energy malnutrition (PEM), iodine deficiency disorders (IDD), vitamin A deficiency (VAD), iron deficiency anaemia (IDA) and other micronutrient deficiencies (DoHS/MOPE). ${ }^{1}$

Some studies have shown that the nutritional condition of Dalit children is very poor in comparison to general children, in Asian countries; however, there is lack of sufficient evidences in Nepalese context. A study conducted in Kapilvastu district of Nepal reported more than $60 \%$ under five children with any kind of malnutrition while measuring by anthropometric measurements. Out of them nearly onefourth children were in critical condition (below -3SD). ${ }^{2}$ The socio-demographic factors like socio-economic status, mother's age, birth order, exclusive breast feeding, and supplementary foods were associated with child health. Another Study conducted in Rupandehi district reported that $65 \%$ children aged between 36 to 59 months were stunted and $46 \%$ were underweight and the figure was more serious among the children of uneducated mothers. ${ }^{3}$ Similarly, the study conducted by Coffey D et al.in India found that the height gap between Scheduled Tribe children and children from general caste, or historically dominant groups were entirely associated with economic wealth and even after accounting for economic differences, an important height shortfall remained for Scheduled Caste. ${ }^{4}$

There is essential to explore the nutritional status of Dalit children along with socio-economic and demographic status. Therefore, the present study has aimed to explore the nutritional status of Dalit children in eastern Terai ecological belt of Nepal along with its comparison to Non-dalit children and also to aims to explore its socio-demographic determinants.

\section{METHODOLOGY}

This study is based on cross-sectional study design. Predesigned, pretested semi-structured interview schedule was used to collect the information. The nutritional status was assessed by the anthropometric measurements: height, weight and Mid-Upper-Arm Circumference (MUAC).

To calculate the sample size a pilot study was conducted among 50 subjects and in an average $30 \%$ under five children were found malnourished. Based on the data of pilot study the sample size was obtained by using following formulae:

$\mathrm{n}=\mathrm{Z}^{2} \times \mathrm{P} \times \mathrm{Q} / \mathrm{d}^{2}$

$=4 \times 70 \times 30 /(7)^{2}$

$=164$ and considering design effect 2

$=328$ again considering $10 \%$ estimated non-responses $\sim 360$

For two groups Dalit and Non Dalit $=360 \times 2=720$

where, $z=1.96, p=$ prevalence rate, $q=1-p, d=\varepsilon p=$ relative probable error

In total, 720 study subjects were involved in this study.

Multistage cluster sampling technique was used to select study districts and VDCs. Three districts: Jhapa, Sunsari and Saptari were selected randomly in the first phase among total 5 districts. Again three VDCs: Surunga from Jhapa, Chhitaha from Sunsar and Inarwa Phulbariya from Saptari were also selected randomly. In third stage, equal numbers $(n=240)$ of study subjects from each VDC were selected using simple random sampling technique from the list of mothers with under-five children. The sampling frame was prepared based on the newest record available from the local health unit (Health Post or Sub-health Post). Face to face interview was taken from the mothers by researchers themselves. Anthropometric measurements (weight, height and MUAC) of children from both Dalit and Non-dalit communities were measured by using standard measurement tools by following standard criteria. Information was collected from 720 mothers about their children who had under-five years in age. Weight was measured from all children and Height and Mid-Upper Arm Circumference (MUAC) were taken only from those children who were 6 months and above in age. Due to children's absence at home, the researchers were able to measure weight of only 705 children, and height and MUAC of 592 children.

Collected information were entered into MS Excel at first and later exported to the SPSS version 16 for analysis. BMI, Midupper-arm circumference, Height for Age, Weight for Height and Weight for Age were categorized according to WHO standard and Mean Z-score were also calculated and then compared between the two caste groups: Dalit and Nondalit. In addition, the socio-demographic determinants were also explored. Bi-variate analysis was done using Pearson's chi-square test and multivariate analysis was done in binary logistic regression. Significance of the test was considered at $95 \%$ confidence interval. The ethical approval was taken from Nepal Health Research Council (NHRC), Kathmandu. 


\section{RESULTS}

\section{Height for age}

Height for age is a nutritional indicator that indicates the growth in height of children according to their age. If the height for age is below - 2 SD from the median value then they are called stunted. Stunting is a widespread problem among Nepalese children.

Table 1: Percentage Distribution of Children according to Height for Age of Children Aged 6-59 Months and Socio-

\begin{tabular}{|c|c|c|c|c|c|c|}
\hline Characteristics & $\mathbf{N}$ & $\begin{array}{c}<-3 \text { SD (Severely } \\
\text { (Stunted) }\end{array}$ & $\begin{array}{l}* *<-2 \text { SD } \\
\text { (Stunted) }\end{array}$ & $\begin{array}{l}\geq-2 S D \\
\text { (Normal) }\end{array}$ & $\begin{array}{l}\text { Mean Z } \\
\text { Score (SD) }\end{array}$ & $\begin{array}{c}\text { Test of } \\
\text { Significance* }\left(\chi^{2}\right)\end{array}$ \\
\hline \multicolumn{7}{|l|}{ Caste } \\
\hline Dalit & 297 & 21.5 & 47.4 & 52.5 & -1.98 & \\
\hline Non-Dalit & 295 & 14.6 & 35.3 & 64.7 & -1.54 & $P=<.001$ \\
\hline \multicolumn{7}{|l|}{ Age of Child (Month) } \\
\hline $6-11$ & 99 & 9.1 & 20.2 & 79.8 & -0.87 & \\
\hline $12-23$ & 190 & 18.9 & 50.0 & 50.0 & -1.88 & \\
\hline $24-47$ & 206 & 17.0 & 43.6 & 56.4 & -2.13 & $P=<.001$ \\
\hline $48-59$ & 97 & 15.5 & 33.0 & 67.0 & -1.63 & \\
\hline \multicolumn{7}{|l|}{ No. of CEB } \\
\hline 1 & 235 & 16.1 & 37.7 & 62.3 & -1.59 & \\
\hline 2 & 226 & 17.1 & 35.9 & $64.1-$ & 1.68 & \\
\hline 3 & 135 & 19.8 & 45.5 & 54.5 & -1.81 & $P=.05$ \\
\hline $4+$ & 109 & 22.0 & 54.9 & 45.1 & -2.20 & \\
\hline \multicolumn{7}{|c|}{ Birth-Spacing (Month) } \\
\hline First Child & 199 & 16.6 & 38.2 & 61.8 & -1.61 & \\
\hline$<24$ & 86 & 23.3 & 41.8 & 58.2 & -1.89 & \\
\hline $24-47$ & 208 & 17.8 & 44.2 & 55.8 & -1.92 & $P=>.05$ \\
\hline$>48$ & 99 & 17.2 & 41.4 & 58.6 & -1.62 & \\
\hline \multicolumn{7}{|l|}{ Sex } \\
\hline Male & 310 & 20.6 & 43.5 & 56.5 & -1.83 & \\
\hline Female & 282 & 15.2 & 39.0 & 61.0 & -1.68 & $p=>.05$ \\
\hline \multicolumn{7}{|l|}{ Wealth Index } \\
\hline 1st Quartile & 189 & 24.9 & 50.3 & 49.7 & -2.07 & \\
\hline 2nd Quartile & 118 & 18.6 & 43.2 & 56.8 & -1.84 & \\
\hline 3rd Quartile & 141 & 17.0 & 33.3 & 66.7 & -1.57 & $\mathrm{P}=<.01$ \\
\hline 4th Quartile & 144 & 9.7 & 36.1 & 63.9 & -1.46 & \\
\hline \multicolumn{7}{|l|}{ Mothers' Education } \\
\hline No Education & 343 & 20.7 & 46.6 & 53.4 & -1.83 & \\
\hline Primary-Secondary & 130 & 15.4 & 34.6 & 65.4 & -1.79 & \\
\hline Grade 10 \& Above & 119 & 13.4 & 33.6 & 66.4 & -1.51 & $P=<.05$ \\
\hline Total & 592 & 18.1 & 41.4 & 58.6 & -1.76 & - \\
\hline
\end{tabular}

*Test of significance taking 3 columns: normal, undernourished and severely undernourished

** Also includes the children below - 3 SD

The height for age of children has been given in table 1 . In total, 41.4 percent children were found stunted $(<-2 \mathrm{SD})$ and among them 18.1 percent were severely malnourished $(<-$ 3SD). The table also reveals whether any socio-demographic factor is associated with the Height for Age. Among the seven variables considered, caste, age of children, numbers of CEB to mother, wealth index and mothers' education were found significantly associated with height for age of children in bi-variate analysis $(p<0.05)$. According to the age of children, 50.0 percent children aged 12-23 months were found below -

\section{demographic Characteristics.}

2SD followed by the children 24-47 months (43.6\%). Number of children ever born (CEB) was negatively associated with the height for age of children. As the number of ever born children increased the percentage of stunting also increased.

Higher proportion (55\%) of children were found stunted 
(below -2 SD) if mother had four and more live births. The mean Z score (SD) was critical among the children with mothers of four and more live births (-2.20). Birth spacing of children had also influenced the height of children; majority of children (61.8\%) of the first birth order had better height than others. Wealth index of family had also significant impact on achieving the height of the children. Children with poor wealth index had more chances to be stunted; 50.3 percent children of $1^{\text {st }}$ quartile wealth index were stunted in comparison to only 36.1 percent children from third quartile
Table 2 describes the result of logistic regression analysis on the determinants of height for age among the children. Age, number of children ever born and mothers' education were found as significant determinants of height for age. The odds of 6-11 month children were two times higher to have normal height than the children of 48 month and above age (AOR:2.08; $\mathrm{Cl}: 1.07$-4.04). The children of mothers having two live birth had nearly two times normal height than the children of mothers with four and more live births (AOR $: 2.02, \mathrm{Cl}: 1.17$ - 3.50). Similarly, the odds of children of mothers with grade $10 \&$ above education having normal

Table 2: Logistic Regression Analysis on Socio-demographic Determinants of Height for Age of Children Aged 6 - 59 Months

Determinants of Height for Age $\quad$ N $\quad$ Logistic Regression Analysis
AOR

\begin{tabular}{|c|c|c|c|}
\hline Caste & & & \\
\hline Dalit & 297 & 1.00 & Ref\# \\
\hline Non-dalit & 295 & 1.36 & $0.92-2.00$ \\
\hline \multicolumn{4}{|l|}{ Age of Children } \\
\hline $6-11$ & 99 & 2.08 & $1.07-4.04^{*}$ \\
\hline $12-23$ & 190 & 0.46 & $0.27-0.77^{* *}$ \\
\hline $24-47$ & 206 & 0.53 & $0.32-0.89 *$ \\
\hline $48+$ & 97 & 1.00 & Ref\# \\
\hline \multicolumn{4}{|l|}{ No. of CEB } \\
\hline One & 199 & 1.47 & $0.83-2.60$ \\
\hline Two & 181 & 2.02 & $1.17-3.50 *$ \\
\hline Three & 121 & 1.36 & $0.77-2.41$ \\
\hline Four + & 91 & 1.00 & Ref\# \\
\hline \multicolumn{4}{|l|}{ Mothers' Education } \\
\hline No Education & 343 & 1.00 & Ref\# \\
\hline Primary/Secondary & 130 & 1.35 & $0.80-2.28$ \\
\hline Grade 10+ & 119 & 1.64 & $1.03-2.61$ \\
\hline \multicolumn{4}{|l|}{ *Wealth Index } \\
\hline $1^{\text {st }}$ Quartile & 189 & 1.00 & Ref\# \\
\hline $2^{\text {nd }}$ Quartile & 118 & 1.28 & $0.68-2.41$ \\
\hline $3^{\text {rd }}$ Quartile & 141 & 1.61 & $0.94-2.73$ \\
\hline $4^{\text {th }}$ Quartile & 144 & 1.29 & $0.79-2.11$ \\
\hline
\end{tabular}

*significant at $95 \% \mathrm{Cl}, * *$ significant at $99 \% \mathrm{Cl}$

$(p<.001)$ and above wealth index. Mean Z score (SD) was found critical among families with $1^{\text {st }}$ quartile wealth index. Education also had better impact on achieving the height of children. Higher percent (46.6\%) children with noneducated mothers were found stunted in comparison to the children of primary and high educated mothers $(p<.05)$. Mean Z score (SD) was also severe among the children of non-educated mother (Table 1 ). height were more than one and half times higher than the children of non-educated mothers (AOR :1.64, Cl : 1.03 2.61).

\section{Weight for Height}

Weight for height parameter is close to the body mass index (BMI) for the children. Among the total study children, about 25 percent were found wasted (<-2SD) including 9.5 percent severely wasted (<-3SD). 
Mother's educational status, caste and wealth index were found significantly associated with the weight for height of children $(p<.05)$. Higher proportions of children with mothers' some education had normal weight for height as compared to the children with non-educated mothers. Similarly, children from families with upper-middle and highest wealth index were less likely to be malnourished as compared to others. The overall mean Z score SD was -1.23 for weight for height of children in the study area. Slight differences in the mean Z score SD was observed according to the mother's education, wealth index, caste, number of CEB and age of children.

In multivariate analysis only mother's education was found significant determinant of weight for height. The odds of children with mothers' education as primary and some secondary were 2.36 times higher $(\mathrm{Cl}: 1.39-4.10)$ and 1.79 times higher $(\mathrm{Cl}: 1.08-2.98)$ as compared to the children of non-educated mothers (table 4).

Table 3: Percentage Distribution of Weight for Height of Children Aged 6-59 Months by Socio-demographic Characteristics

\begin{tabular}{|c|c|c|c|c|c|c|}
\hline Characteristics & $\mathbf{N}$ & $\begin{array}{c}<-3 \text { SD } \text { (Severely } \\
\text { (wasted) }\end{array}$ & $\begin{array}{l}* *<-2 \text { SD } \\
\text { (wasted) }\end{array}$ & $\begin{array}{l}\geq-2 S D \\
\text { (Normal) }\end{array}$ & $\begin{array}{l}\text { Mean Z } \\
\text { Score (SD) }\end{array}$ & $\begin{array}{c}\text { Test of } \\
\text { Significance }{ }^{*}\left(\chi^{2}\right)\end{array}$ \\
\hline \multicolumn{7}{|l|}{ Caste } \\
\hline Dalit & 297 & 11.8 & 29.0 & 71.0 & -1.32 & \\
\hline Non-Dalit & 295 & 7.1 & 20.3 & 79.7 & -1.14 & $P=<.05$ \\
\hline \multicolumn{7}{|l|}{ Age of Child (Month) } \\
\hline $6-11$ & 99 & 14.1 & 24.2 & 75.7 & -1.20 & \\
\hline $12-23$ & 190 & 9.5 & 24.2 & 75.8 & -1.09 & \\
\hline $24-47$ & 206 & 6.3 & 22.2 & 77.7 & -1.17 & $P=>.05$ \\
\hline $48-59$ & 97 & 11.3 & 33.9 & 69.1 & -1.66 & \\
\hline \multicolumn{7}{|l|}{ No. of CEB } \\
\hline 1 & 235 & 8.0 & 25.1 & 74.9 & -1.09 & \\
\hline 2 & 226 & 9.4 & 23.8 & 76.2 & -1.32 & \\
\hline 3 & 135 & 9.9 & 22.3 & 77.7 & -1.18 & $P=>.05$ \\
\hline $4+$ & 109 & 12.1 & 28.6 & 71.4 & -1.44 & \\
\hline \multicolumn{7}{|l|}{ Birth-Spacing } \\
\hline First Child & 199 & 8.5 & 25.6 & 74.4 & -1.14 & \\
\hline$<24$ & 86 & 8.1 & 29.0 & 70.9 & -0.98 & \\
\hline $24-47$ & 208 & 11.5 & 25.0 & 75.0 & -1.40 & $P=>.05$ \\
\hline$>48$ & 99 & 8.1 & 18.2 & 81.8 & -1.27 & \\
\hline \multicolumn{7}{|l|}{ Sex } \\
\hline Male & 310 & 9.4 & 23.5 & 76.5 & -1.17 & \\
\hline \multirow[t]{2}{*}{ Female } & 282 & 9.6 & 25.9 & 74.2 & -1.30 & \\
\hline & & & & & & $p=>.05$ \\
\hline \multicolumn{7}{|l|}{ Wealth Index } \\
\hline 1st Quartile & 189 & 9.5 & 27.1 & 73.0 & -1.31 & \\
\hline 2nd Quartile & 118 & 9.3 & 31.3 & 68.6 & -1.39 & \\
\hline 3rd Quartile & 141 & 12.8 & 23.4 & 76.6 & -1.29 & $P=<.05$ \\
\hline 4th Quartile & 144 & 6.2 & 17.3 & 82.6 & -0.94 & \\
\hline \multicolumn{7}{|l|}{ Mothers' Education } \\
\hline No Education & 343 & 12.0 & 30.0 & 70.0 & -1.37 & \\
\hline Primary-Secondary & 130 & 4.6 & 15.4 & 84.6 & -1.01 & \\
\hline Grade 10 \& Above & 119 & 7.6 & 19.4 & 80.6 & -1.08 & $P=<.001$ \\
\hline Total & 592 & 9.5 & 24.7 & 75.3 & -1.23 & - \\
\hline
\end{tabular}

*Test of significance taking 3 columns: normal, undernourished and severely undernourished

** Also includes the children below - 3 SD. 
Table 4: Logistic Regression analysis on Socio-demographic Determinants of Weight for Height of Children Aged 6 - 59 Months

Determinants of Height for Age

Logistic Regression Analysis

AOR

$\mathrm{Cl}$

\section{Caste \\ Dalit}

Non-dalit

\section{Education of Mother}

No Education

Primary/Secondary

Grade 10+

\section{*Wealth Index}

$1^{\text {st }}$ Quartile
$2^{\text {nd }}$ Quartile
$3^{\text {rd }}$ Quartile
$4^{\text {th }}$ Quartile

$1^{\text {st }}$ Quartile

4 Quartile

$*$ significant at $95 \% \mathrm{Cl},{ }^{* *}$ significant at $99 \% \mathrm{Cl}$

\section{Weight for Age}

Weight for age is one of the most common indicator to measure nutritional status of children has given in table no. 5 . Among 705 children measured successfully, 38.6 percent were found underweight (<-2SD) and 13.6 were severely underweight (<-3SD).

Education, wealth Index, caste, age of children and numbers of children ever born were significantly associated with the weight for age $(p<.05)$. About one and half times higher proportion of Dalit children (46.4\%) were underweight as compared to Non-dalit (30.7\%) and children of aged 2 years and above were more vulnerable to be underweight than those below 2 years.

Higher proportion of first (64.3\%) and second (66.4\%) order live births had better weight than the forth order and more (46.8\%). Mother's education was highly significant in maintaining the normal weight; underweighted children without mother's education were nearly two times higher than the children of educated mothers'. Similarly, the variation is also found in mean Z score (SD) of weight for age according to the socio-demographic status. Children of age below 6 months had better (-1.02) mean Z score than the children aged 24-47(-2.03) and 48-59 months (-2.10), (Table 5).

\section{Table 5: Percentage Distribution of Children according to Weight for Age and Socio-demographic Characteristics}

\begin{tabular}{|c|c|c|c|c|c|c|}
\hline Characteristics & $\mathbf{N}$ & $\begin{array}{c}\text { <-3 SD } \\
\text { (Severely } \\
\text { underweight }\end{array}$ & $\begin{array}{l}* *<-2 \text { SD } \\
\text { (Under } \\
\text { weight }\end{array}$ & $\begin{array}{c}\geq-2 S D \\
\text { (Normal) }\end{array}$ & $\begin{array}{l}\text { Mean Z } \\
\text { Score (SD) }\end{array}$ & $\begin{array}{c}\text { Test of } \\
\text { Significance }\left(\chi^{2}\right)\end{array}$ \\
\hline \multicolumn{7}{|l|}{ Caste } \\
\hline Dalit & 353 & 18.1 & 46.4 & 53.5 & -1.90 & \\
\hline Non-Dalit & 352 & 9.1 & 30.7 & 69.3 & -1.55 & $P=<.001$ \\
\hline \multicolumn{7}{|l|}{ Age (in Month) } \\
\hline$<6$ & 111 & 5.4 & 16.2 & 83.8 & -1.02 & \\
\hline $6-11$ & 100 & 13.0 & 37.0 & 63.0 & -1.44 & \\
\hline $12-23$ & 190 & 13.7 & 38.4 & 61.6 & -1.73 & $P=>.001$ \\
\hline $24-59$ & 207 & 16.4 & 47.3 & 52.7 & -2.03 & \\
\hline $48-59$ & 97 & 17.5 & 47.4 & 52.6 & -2.10 & \\
\hline
\end{tabular}




\section{No. of CEB}

\begin{tabular}{|c|c|c|c|c|c|c|}
\hline 1 & 235 & 11.1 & 35.7 & 64.3 & -1.54 & \\
\hline 2 & 226 & 14.2 & 33.6 & 66.4 & -1.66 & \\
\hline 3 & 135 & 11.1 & 40.0 & 60.0 & -1.78 & $\mathrm{P}=<.01$ \\
\hline $4+$ & 109 & 21.1 & 53.2 & 46.8 & -2.15 & \\
\hline \multicolumn{7}{|l|}{ Birth-Spacing } \\
\hline First Child & 235 & 11.5 & 36.2 & 63.8 & -1.58 & \\
\hline$<24$ Month & 108 & 14.8 & 43.5 & 56.5 & -1.61 & \\
\hline 24-47 Month & 245 & 16.3 & 40.0 & 60.0 & -1.92 & $P=>.05$ \\
\hline 48 \& Above & 117 & 11.1 & 35.9 & 64.1 & -1.72 & \\
\hline \multicolumn{7}{|l|}{ Wealth Index } \\
\hline $1^{\text {st }}$ Quartile & 189 & 17.3 & 42.7 & 57.3 & -1.95 & \\
\hline $2^{\text {nd }}$ Quartile & 118 & 15.2 & 43.7 & 56.3 & -1.77 & \\
\hline $3^{\text {rd }}$ Quartile & 141 & 14.3 & 39.8 & 60.2 & -1.78 & $\mathrm{P}=<.05$ \\
\hline $4^{\text {th }}$ Quartile & 144 & 6.9 & 27.7 & 72.3 & -1.32 & \\
\hline \multicolumn{7}{|l|}{ Sex } \\
\hline Male & 355 & 13.8 & 38.3 & 61.7 & -1.73 & \\
\hline \multirow[t]{2}{*}{ Female } & 350 & 13.4 & 38.9 & 61.1 & -1.72 & \\
\hline & & & & & & $p=>.05$ \\
\hline \multicolumn{7}{|l|}{ Mothers' Education } \\
\hline No Education & 410 & 18.0 & 45.1 & 54.9 & -1.90 & \\
\hline Primary-Secondary & 153 & 7.2 & 32.7 & 67.3 & -1.50 & \\
\hline Grade 10 \& Above & 142 & 7.7 & 26.1 & 73.9 & -1.45 & $\mathrm{P}=<.001$ \\
\hline Total & 705 & 13.6 & 38.6 & 61.4 & -1.72 & - \\
\hline
\end{tabular}

*Test of significance taking 3 columns: normal, undernourished and severely undernourished

** Also includes the children below - 3 SD.

Table 6 : Logistic Regression analysis on Socio-demographic Determinants of Weight for Age of Children

\begin{tabular}{|c|c|c|c|}
\hline \multirow[t]{2}{*}{ Determinants of Height for Age } & \multirow[t]{2}{*}{$\mathbf{N}$} & \multicolumn{2}{|c|}{ Weight for Age } \\
\hline & & AOR & $\mathrm{Cl}$ \\
\hline \multicolumn{4}{|l|}{ Caste } \\
\hline Dalit & 353 & Ref \# & - \\
\hline Non-dalit & 352 & 1.55 & $1.09-2.21^{*}$ \\
\hline \multicolumn{4}{|l|}{ Age of Child (Month) } \\
\hline$<6$ & 111 & 5.08 & $2.63-9.81^{* * *}$ \\
\hline $6-11$ & 100 & 1.59 & $0.89-2.85$ \\
\hline $12-23$ & 190 & 1.44 & $0.87-2.39$ \\
\hline $24-47$ & 207 & 0.98 & $0.60-1.62$ \\
\hline $48+$ & 97 & 1.00 & Ref\# \\
\hline \multicolumn{4}{|l|}{ No. of CEB } \\
\hline 1 & 235 & 1.44 & $0.80-2.56$ \\
\hline 2 & 226 & 1.98 & $1.14-3.44^{*}$ \\
\hline 3 & 135 & 1.33 & $0.75-2.37$ \\
\hline $4+$ & 109 & 1.00 & Ref\# \\
\hline \multicolumn{4}{|l|}{ Education } \\
\hline No Education & 410 & 1.00 & Ref\# \\
\hline Primary/Secondary & 153 & 1.87 & $1.16-3.02 * *$ \\
\hline Grade $10+$ & 142 & 1.62 & $1.07-2.45^{*}$ \\
\hline \multicolumn{4}{|l|}{ Decision - Making } \\
\hline No & 401 & 1.00 & Ref\# \\
\hline Yes & 304 & 1.31 & $0.95-1.82$ \\
\hline
\end{tabular}

$*$ significant at $95 \% \mathrm{Cl}, * *$ significant at $99 \% \mathrm{Cl}, * * *$ significant at $99.9 \% \mathrm{Cl}$ 
The result of multivariate analysis confirmed that the caste, not-educated mothers to gain better weight for age. The age of children, numbers of ever born children and education of mothers were significant determinants of weight for age of the children. The remarkable variation is that the odds of having normal weight in children less than 6 months was 5.08 ( $\mathrm{Cl}: 2.63-9.81$ ) times higher than the children of 48 months \& above. Similarly, the odds of Non-dalit children gaining normal weight was 1.55 (Cl: 1.09 - 2.21) times higher than the Dalit children. Education was also another significant determinant of weight for age. Children of educated mothers had higher chances of getting normal weight as compared to the children of not-educated mothers. The children with mothers' primary-secondary education had $1.87(\mathrm{Cl}: 1.16-3.02)$ times higher and with mothers' education grade $10 \&$ above had 1.62 ( $\mathrm{Cl}: 1.07-2.45$ ) times higher odds than the children of decision-making capacity of mothers also had some influence for gaining normal weight of children (table 6).

\section{Mid-Upper-Arm Circumference (MUAC)}

Mid-Upper-Arm circumference of children determines the muscle volume in the body. In the present study, in total, 21.4 percent children had MUAC below -2SD indicating malnutrition. While observing by socio-demographic backgrounds, the figure was worse among the Dalit caste than Non-dalit ( $p<.001)$; children of age group 6-11 months had better MUAC than children of older ages. As the age of children increasing, proportion of normal MUAC $(p<.001)$ was observed decreasing (Table 7).

\section{Table 7: Percent Distribution of Children according to Mid-Upper-Arm circumference (MUAC) by Socio-demographic} Characteristics

\begin{tabular}{|c|c|c|c|c|c|}
\hline Characteristics & $\mathbf{N}$ & $\begin{array}{l}<-3 \text { SD (Severely } \\
\text { (Severe } \\
\text { Malnourished }\end{array}$ & $\begin{array}{c}*<-2 \text { SD } \\
\text { (Malnourished) }\end{array}$ & $\begin{array}{c}\geq-2 S D \\
\text { (Normal) }\end{array}$ & $\begin{array}{c}\text { Test of } \\
\text { Significance }\left(\chi^{2}\right)\end{array}$ \\
\hline \multicolumn{6}{|l|}{ Caste } \\
\hline Dalit & 297 & 4.7 & 29.3 & 70.4 & \\
\hline Non-Dalit & 295 & 1.4 & 13.6 & 84.4 & $\mathrm{P}=<.001$ \\
\hline \multicolumn{6}{|l|}{ Age of Child (Month) } \\
\hline 6-11 & 99 & 0.0 & 9.1 & 90.9 & \\
\hline $12-23$ & 190 & 2.6 & 20.5 & 79.5 & \\
\hline $24-47$ & 206 & 3.9 & 23.3 & 76.7 & $P=<.001$ \\
\hline $48-59$ & 97 & 5.2 & 32.0 & 68.0 & \\
\hline \multicolumn{6}{|l|}{ Birth Spacing (Month) } \\
\hline First Child & 199 & 1.5 & 18.6 & 81.4 & \\
\hline$<24$ & 86 & 0.0 & 23.3 & 76.7 & \\
\hline $24-47$ & 208 & 4.8 & 23.1 & 76.9 & $\mathrm{P}=<.001$ \\
\hline$>48$ & 99 & 5.1 & 22.3 & 77.8 & \\
\hline \multicolumn{6}{|l|}{ Sex } \\
\hline Male & 310 & 2.9 & 20.0 & 80.0 & \\
\hline Female & 282 & 3.2 & 23.1 & 77.0 & $p=.00$ \\
\hline \multicolumn{6}{|l|}{ Wealth Index } \\
\hline Low & 9.5 & 31.2 & 67.2 & 1.6 & \\
\hline Lower-middle & 11.0 & 29.6 & 66.9 & 3.4 & \\
\hline Upper-middle & 14.2 & 29.1 & 70.2 & 0.7 & $\mathrm{P}=<.001$ \\
\hline High & 8.3 & 19.4 & 79.2 & 1.4 & \\
\hline \multicolumn{6}{|l|}{ Mother's Education } \\
\hline No Education & 343 & 4.7 & 27.4 & 67.9 & \\
\hline Primary- some Secondary & 130 & 0.8 & 13.9 & 83.1 & \\
\hline Grade 10 \& Above & 119 & 0.8 & 12.6 & 84.9 & $P=<.001$ \\
\hline Total & 592 & 3.0 & 21.4 & 78.6 & - \\
\hline
\end{tabular}

*Also includes the children below -3 SD 
Birth spacing of children was also significantly associated with MUAC $(p<.001)$. The first child had better MUAC status as compared to others. Higher percentage of female children had MUAC thinner as compared to male children. Education of mother again has significant impact on the MUAC status of children. Twenty seven (27.4\%) percent children with noneducated mother had MUAC below -2SD and 4.7 percent had below -3SD, however the same figure was better among the children of educated mothers $(p<.001)$.

The multivariate logistic regression analysis was done and only wealth index was found significant determinant of MidUpper Arm Circumference. The odds of children from the family of highest and second highest wealth index were 3.05 $(\mathrm{Cl}: 1.75-5.29)$ and $3.12(\mathrm{Cl}: 1.82-5.35)$ times higher times higher for obtaining normal MUAC than the children of lowest wealth index (table 8). stunted, 9.5 percent were severely wasted and 13.6 percent were severely underweight. Mean Z score was also calculated to find out the severity of malnutrition. The average Z score was -1.76 SD for height for age, -1.72 SD for weight for age and -1.23 SD for weight for height. Similarly, 21 percent children had MUAC below -2SD and the Mean MUAC was found $13.7 \mathrm{~cm}$. While observing according to the socio-demographic characteristics caste, mother's education and wealth index of family were strongly associated with all three indicators i.e. height for age, weight for height and weight for age. In addition, age, number of children ever born (CEB) and birth spacing also positively associated with height for age and age and number of CEB with weight for height.

While adjusting with caste, age, sex, birth spacing, number of CEB, wealth index, mother's education and mother's decision making capacity in multivariate analysis, only caste, number of CEB and mother's education were found as

\section{Table 8: Logistic Regression analysis on Socio-demographic Determinants of MUAC of Children}

\begin{tabular}{|c|c|c|c|c|}
\hline \multicolumn{2}{|c|}{ Determinants of Height for Age } & \multirow[t]{2}{*}{$\mathbf{N}$} & \multicolumn{2}{|c|}{ Logistic Regression Analysis } \\
\hline & & & AOR & $\mathrm{Cl}$ \\
\hline \multirow[t]{4}{*}{ Wealth Index } & $1^{\text {st }}$ Quartile & 189 & 1.00 & Ref\# \\
\hline & $2^{\text {nd }}$ Quartile & 118 & 2.06 & $1.26-3.37 * *$ \\
\hline & $3^{\text {rd }}$ Quartile & 141 & 3.16 & $1.82-5.35^{* * *}$ \\
\hline & $4^{\text {th }}$ Quartile & 144 & 3.05 & $1.75-5.29 * * *$ \\
\hline
\end{tabular}

$*$ significant at $95 \% \mathrm{Cl}, * *$ significant at $99 \% \mathrm{Cl}, * * *$ significant at $99.9 \% \mathrm{Cl}$

\section{DISCUSSION}

Adequate nutrition is prerequisite for all the individuals to maintain their health; however, more focus has to be given particularly women and children who are especially vulnerable to it. Problems related to malnutrition affect the population of all ages and areas; women and children are especially vulnerable because of their unique physiology and socioeconomic backgrounds. ${ }^{5}$ Women's nutrient needs increase during pregnancy and lactation. If the requirements are not met, the consequences can be serious particularly for their infants. ${ }^{6}$ The poor nutritional status of children has been considered a serious issue in Nepal for many years. The malnutrition status has been trying to assess by anthropometric measurements in this study to understand the real situation among Dalit children along with its comparison with Non-dalit. The height for age, weight for height, weight for age, mid-upper-arm circumference (MUAC) and mean Z score (SD) were obtained and compared between groups according to the WHO standard.

In total, 41 percent children were found stunted (<2SD), 24.7 percent wasted and 38.6 percent underweight. Moreover, the prevalence of severe malnutrition was also high in children. Eighteen percent children were severely (<-3SD) significant determinants of height for age. Mother's education was found significant predictor (determinant) for weight for height. Similarly, Caste, age of children and mother's education were found as significant determinants of weight for age.

The finding of NDHS 2011 is similar with present finding except wasting, they indicated that 39 percent children were stunted, 29 percent underweight and 11 percent were wasted. Wasting found higher in present study. They also found that the problem was deeper among the Dalit, low income households and non-educated mothers' children. ${ }^{6}$ Later Panday JP et al (2013) further analysed NDHS 2011 data and found almost similar results. They found that caste/ethnicity, age of child and wealth index were significant predictors of weight of age of the children along with delivery by an SBA. ${ }^{7}$ Another study by Shah N (2004) also reported similar finding as the present study. They analyzed the final survey of Child Nutrition Program 2003 data and found that older children (above 36 month) and children whose mothers were illiterate were more likely to be underweight and stunted. $^{8}$ 
Girma et al (2002) conducted further analysis of DHS 2000 data, Ethiopia and found in a multivariate analysis that religion, education of mother and father, economic status of household, age of child, birth order (only first), and birth interval as significant predictor variables of stunting among the children.' Pongou et al. (2006) analyzed the Demographic Health Survey of 1991 and 1998 data from Cameroon. They found average weight for age (Weight for Age Z score) and height for age (Height for Age Z score) declined between 1991 and 1998. This decline occurred mostly among boys, children over 12 months of age, and those with low socio-economic status. Maternal education and maternal health seeking behaviour were associated with better child nutrition. Household economic status had an overall positive effect but it had little effect in children less than 6 months of age. ${ }^{10}$

The caste, age, wealth index and education of mothers were found significantly associated with the MUAC of children in this study. More proportion of children between 6-11 months, the first birth and children with mothers' some education had better MUAC. Dalit caste Children of not educated mothers, from lowest and second lowest wealth index and older age-group were more vulnerable to be undernourished.

Among all variables, the education of mother was found to be the most significant determinant for all parameters of child nutrition and the effect of wealth index of the family

\section{REFERENCES}

1. Ministry of Health and Population, New Era and Macro International Inc. USA. Nepal Demographic and Health Survey 2006, Final Report (Kathmandu: New ERA).

2. Bhandari TR, Chhetri M. Nutritional Status of Under Five Year Children and Factors Associated in Kapilvastu District, Nepal. J Nutrition Health Food Sci 2013; 1(1):2-6.

3. Acharya D, Gautam S, Kaphle HP and Neupane N. Factors Associated with Nutritional Status of Under Five Children in Rupandehi District of Nepal. JHAS, 2013; Vol. 3, No. 1, P 56-59.

4. Coffey D, Deshpande A, Jeffrey H and Spears D. Wealth, hierarchy, and child height in Indian social groups. Working Paper; September 27, 2014. [Internet] available at: http://paa2015.princeton.edu/ uploads/152381. [Accessed: 20 February 2017].

5. Ministry of Health and Population, New Era and Macro International Inc. USA. Nepal Demographic and Health Survey 2011.

6. Christian, P. Maternal Nutrition, Health and Survival. Nutr Rev. 2002;60(5 Pt 2):S59-63. [PMID: 12035860]. had also significant effect. This result is closely similar with a study conducted by Mishra SK et al in Kanti Children Hospital Kathmandu, Nepal. They revealed that the children of literate mothers had better anthropometric measurements than children of illiterate mothers. ${ }^{11}$

Though there are many efforts have been made to improve the nutritional status of children, the problem of malnutrition is still very high in Nepalese children and it needs a special focus of family, communities as well as the government authorities.

\section{LIMITATION OF THE STUDY}

This study has not covered all components of nutrition; only anthropometric measurements were taken and sociodemographic determinants were explored.

The anthropometric measurements could not be obtained from all children as some of them were absent during data collection

\section{ACKNOWLEDGEMENT}

Researchers are thankful to the Nepal Health Research Council, ethical review board for the approval of this study. We also thankful to participants of eastern Terai, Nepal as well as enumerators Tejika Adhikari and Indu Yadav.

\section{CONFLICT OF INTEREST}

No conflict of interest
7. Pandey JP, Dhakal MR, Karki S, Poudel P and Pradhan MS. Maternal and Child Health in Nepal: The Effects of Caste, Ethnicity, and Regional Identity: Further analysis of the 2011 Nepal Demographic and Health Survey (Calverton, Maryland, USA: Nepal Ministry of Health and Population, New ERA, and ICF International), 2013.

8. Shah N. Determinants of Child Nutrition in Nepal: A case Study from Dhanusha, Central Terai of Nepal. Journal of Nepal Health Research Council 2004; Vol. 2 No. 2, pp: 50-54.

9. Girma W and Timotiows G. Determinants of Nutritional Status of Women and Children in Ethiopia. Calverton, Maryland, USA: ORC Macro. 2002.

10. Pongou R, Ezzati $\mathrm{M}$ and Salomon JA. Household and Community Socioeconomic and Environmental Determinants of Child Nutritional Status in Cameroon. BMC Public Health 6:98. 2006.

11. Mishra SK, Bastola SP, Jha B. Biochemical nutritional indicators in children with protein energy malnutrition attending Kanti Children Hospital, Kathmandu, Nepal. Kathmandu University Medical Journal 2009; Vol. 7, No. 2, Issue 26, 129-134. 